\title{
Patient Self-Report
}

National Cancer Institute

\section{Source}

National Cancer Institute. Patient Self-Report. NCI Thesaurus. Code C21089.

Subjective reports made by a patient. 